Global Conferences Series:

Sciences and Technology (GCSST), Volume,5, 2020

Seminar Nasional I Baristand Industri Padang (Semnas I BIPD)

DOI:https://doi.org/10.32698/GCS-SNIIBIPD3442

\title{
Hydrolysis of durian seed flour (Durio zibethinus) into glucose using acetic acid catalyst
}

\section{Hidrolisis tepung biji durian (Durio zibethinus) menjadi glukosa menggunakan katalis asam asetat}

\author{
Erti Praputri ${ }^{1}$, Elmi Sundari ${ }^{1}$, dan S. Sofyan ${ }^{2}$ \\ ${ }^{1}$ Prodi Teknik Kimia, Fakultas Teknologi Industri, Universitas Bung Hatta, Padang, Indonesia \\ ${ }^{2}$ Balai Riset dan Standardisasi Industri, Padang, Indonesia \\ E-mail: ertipraputri@yahoo.co.id
}

\begin{abstract}
Glucose is a chemical that is widely used in the industrialization era which is produced through the hydrolysis process of raw materials containing starch. One source of starch is durian seeds (Durio zibethinus) which contain $54.14 \%$ starch. About $5-15 \%$ of durian fruit are seeds which are waste. The process of hydrolysis of starch to glucose is very slow, so a catalyst is needed to speed up the reaction. Several studies have used $\mathrm{HCl}, \mathrm{H}_{2} \mathrm{SO}_{4}$, and enzymes as catalysts. Especially for durian seeds, no one has used acetic acid as a catalyst. Acetic acid is more environmentally friendly, but information about the ability of acetic acid to increase glucose levels compared to $\mathrm{HCl}$ and $\mathrm{H}_{2} \mathrm{SO}_{4}$ is still very little. The aim of this research was to see the performance of acetic acid catalyst at various operating conditions at certain concentrations of hydrolysis time and temperature. The research was conducted with variations in the concentration of glacial acetic acid (2.5; 10; 25\%), hydrolysis time (2, 3, 4 hours), and hydrolysis temperature $\left(70,90,110^{\circ} \mathrm{C}\right)$. The results showed that temperature and time played a greater role in the hydrolysis process. Increase in temperature and time will increase glucose levels. The highest glucose levels obtained in this study were at a concentration of $2.5 \%$ acetic acid, a temperature of $110^{\circ} \mathrm{C}$, and a time of 240 minutes with a glucose level of $158.5 \mathrm{mg} / \mathrm{dl}$.
\end{abstract}

Keywords: durian seed; starch; catalyst; glucose; acetic acid

Abstrak: Glukosa adalah bahan kimia yang banyak digunakan dalam era industrialisasi yang dihasilkan melalui proses hidrolisis dari bahan baku yang mengandung pati. Salah satu sumber pati adalah biji durian (Durio zibethinus) yang mengandung 54,14\% pati. Sekitar 5-15\% dari buah durian adalah biji yang merupakan limbah. Proses hidrolisis pati menjadi glukosa berlangsung sangat lambat sehingga dibutuhkan katalis untuk mempercepat reaksi. Beberapa studi menggunakan $\mathrm{HCl}, \mathrm{H}_{2} \mathrm{SO}_{4}$, dan enzim sebagai katalis. Khusus untuk biji durian, belum ada yang menggunakan asam asetat sebagai katalis. Asam asetat lebih ramah lingkungan, namun informasi tentang kemampuan asam asetat dalam meningkatkan kadar glukosa dibandingkan $\mathrm{HCl}$ dan $\mathrm{H}_{2} \mathrm{SO}_{4}$ masih sangat sedikit. Penelitian bertujuan melihat kinerja katalis asam asetat pada berbagai kondisi operasi waktu dan temperatur hidrolisis dengan konsentrasi tertentu. Penelitian dilakukan dengan variasi konsentrasi asam asetat glacial $(2,5 ; 10 ; 25 \%)$, waktu hidrolisis $(2,3,4$ jam $)$, dan suhu hidrolisis $\left(70,90,110^{\circ} \mathrm{C}\right)$. Hasil penelitian menunjukkan bahwa temperatur dan waktu lebih berperan dalam proses hidrolisis. Kenaikan temperatur dan waktu akan meningkatkan kadar glukosa. Kadar glukosa tertinggi yang diperoleh dalam penelitian ini adalah pada konsentrasi asam asetat $2,5 \%$, temperatur $110^{\circ} \mathrm{C}$, dan waktu 240 menit dengan kadar glukosa $158,5 \mathrm{mg} / \mathrm{dl}$.

Kata kunci: biji durian; pati; katalis; glukosa; asam asetat

Copyright (C) 2020, the Authors. Published by Redwhite Press. 


\section{PENDAHULUAN}

Glukosa adalah bahan kimia yang banyak digunakan dalam era industrialisasi di Indonesia pada saat ini. Glukosa dapat dibuat dari bermacam-macam bahan baku yang mengandung pati (Iryani, 2013) diantaranya adalah biji durian. Pada musim durian, limbah yang berupa kulit dan biji cukup banyak tersedia (Sistanto et al., 2017). Bagian yang umum dikonsumsi adalah daging atau salut buah yang persentasenya hanya sekitar 20-35\%, sedangkan bagian kulit 60-75\% dan biji 5-15\%. (Djaeni et al., 2012). Disisi lain, biji durian (Durio Zibethinus) mengandung kadar pati yang tinggi yaitu 54,14\%. Pati secara umum adalah bahan utama yang dihasilkan oleh tumbuhan untuk menyimpan glukosa (sebagai produk fotosintesis) dalam jangka panjang. Pati biji durian dapat dijadikan salah satu sumber bahan baku untuk menghasilkan glukosa yang nantinya dikonversi menjadi bioetanol. Konversi pati menjadi glukosa dilakukan melalui proses hidrolisis (Hapsari and Pramashinta, 2013).

Hidrolisis adalah suatu proses antara reaktan dengan air agar suatu senyawa pecah atau terurai. Namun reaksi antara pati dan air berlangsung sangat lambat sehingga diperlukan bantuan katalisator untuk memperbesar kereaktifan air (Mastuti and Setyawardhani, 2010). Katalis adalah suatu zat yang mempercepat laju reaksi kimia pada suhu tertentu dengan menurunkan energi aktivasi, tanpa mengalami perubahan oleh reaksi itu sendiri. Jenis katalisator yang telah digunakan pada proses hidrolisis adalah asam (asam kuat dan asam lemah) dan enzim (Dewi et al., 2018). Asam asetat terogolong asam lemah namun ramah lingkungan. Peneliti lainnya, (Nurjati and Buchor, 2012) menggunakan katalis $\mathrm{HCl}$ pada hidrolisis bonggol pisang, mendapatkan glukosa sebesar 13,6 \%. (Praputri et al., 2018) menggunakan $\mathrm{H}_{2} \mathrm{SO}_{4}$ pada proses hidrolisis umbi singkong karet mendapatkan glukosa sebesar 27,25\%. Penggunaan asam asetat pada proses hidrolisis juga pernah dilakukan oleh beberapa peneliti diantaranya (Uppal and Kaur, 2011) untuk menghidrolisis bagas tebu. (Mastuti and Setyawardhani, 2010), (Murniati et al., 2018) menggunakan katalis $\mathrm{H}_{2} \mathrm{SO}_{4}$ pada hidrolisis biji durian, menghasilkan glukosa $13,08 \%$.

Penggunaan $\mathrm{HCl}$ dan $\mathrm{H}_{2} \mathrm{SO}_{4}$ sering menimbulkan permasalahan pada lingkungan seperti korosi pada alat. Katalis asam kuat mengakibatkan terbentuknya produk samping antara lain hasil reaksi Maillard sehingga produk berwarna coklat kehitaman (Mei et al., 2015). (Neni et al., 2013) menyatakan bahwa asam asetat dapat dipertimbangkan sebagai katalis pada proses hidrolisis karena lebih ramah lingkungan. Asam asetat berasal dari bahan alam yang dapat diperbaharui dan relatif tidak korosif terhadap alat bila dibandingkan dengan menggunakan asam kuat.

Informasi tentang kemampuan asam asetat dalam meningkatkan kadar glukosa pada proses hidrolisis masih sangat terbatas. Penelitian ini bertujuan melihat kinerja katalis asam asetat pada berbagai kondisi operasi waktu dan temperatur hidrolisis dengan konsentrasi tertentu.

\section{METODE}

Bahan-bahan yang digunakan yaitu biji durian, $\mathrm{HCl} 3 \%, \mathrm{CH}_{3} \mathrm{COOH}$ (asam asetat p.a), asam cuka, aquades, dan aluminium foil. Biji durian yang digunakan merupakan limbah yang diperoleh dari penjual durian di kota Padang. Asam asetat yang digunakan yaitu asam asetat p.a, diproduksi oleh Brataco dan asam cuka yang diproduksi oleh Usaha Niaga Padang. Peralatan yang digunakan adalah neraca analitik, oven, autoclave, hot plate, termometer, dan peralatan gelas.

\section{Perlakuan Penelitian}

Penelitian dilakukan dalam 2 tahap. Tahap 1 yaitu pembuatan tepung biji durian dan tahap 2 yaitu proses hidrolisis tepung biji durian menjadi glukosa. Penelitian dilakukan dengan variasi konsentrasi asam asetat $(2,5 \% ; 10 \%$; dan $25 \%)$ yang dibuat dengan mengencerkan asam asetat p.a. Konsentrasi asam asetat yang tersedia dipasaran adalah $15 \%$. Temperatur hidrolisis divariasikan $\left(70^{\circ} \mathrm{C}, 90^{\circ} \mathrm{C}\right.$, dan $\left.110^{\circ} \mathrm{C}\right)$ dan waktu hidrolisis dilakukan selama 2, 3, dan 4 jam.

\section{Pembuatan Tepung Biji Durian}

Biji durian yang diperoleh dari pedagang masih diselimuti oleh sisa daging buah dan kulit ari. Prosedur pembuatan tepung biji durian diawali dengan pencucian biji durian agar bersih dari daging buah yang masih menempel. Kulit ari biji durian dipisahkan dengan mengupas kulit arinya. Untuk memperkecil ukurannya, biji durian dipotong-potong dengan ukuran $1,5 \mathrm{~cm}$. Untuk menghilangkan getah/lendir yang terdapat dalam biji durian, maka potongan biji durian dicuci kembali menggunakan campuran air (1000 ml) dan garam (200 gram) lalu dikeringkan dalam oven pada suhu $100{ }^{\circ} \mathrm{C}$ selama 48 jam sampai kadar air 
tertentu (mudah ditumbuk dan tidak lengket pada wadah penumbukan). Biji durian yang telah kering dihaluskan dan diayak untuk mendapatkan ukuran tepung 120 mesh. Hasil pengayakan merupakan tepung biji durian yang siap digunakan untuk hidrolisis.

\section{Proses Hidrolisis Tepung Biji Durian}

Proses hidrolisis diawali dengan menimbang 25 gram tepung biji durian. Tepung biji durian dimasukkan ke dalam erlenmeyer $500 \mathrm{ml}$ dan ditambahkan $250 \mathrm{ml}$ asam asetat $\left(\mathrm{CH}_{3} \mathrm{COOH}\right)$, sesuai dengan konsentrasi yang telah ditetapkan. Selanjutnya ditutup dengan aluminium foil. Larutan tepung biji durian lalu dipanaskan menggunakan autoclave pada $110^{\circ} \mathrm{C}$ selama 4 jam. Selanjutnya larutan didinginkan hingga suhu kamar $\left(20-30^{\circ} \mathrm{C}\right)$. Setelah dingin, sampel disaring dan hasil saringan (filtrat) yang bersifat asam ditambah $\mathrm{NaOH} 30 \%$ hingga mencapai $\mathrm{pH}$ netral

\section{Pengujian}

Pengujian yang dilakukan pada penelitian ini adalah kadar pati dan kadar glukosa tepung biji durian. Pengujian kadar pati diawali dengan menimbang tepung biji durian sebanyak 25 gram dimasukkan ke dalam erlenmeyer $500 \mathrm{ml}$ dan ditambahkan $250 \mathrm{ml} \mathrm{CH} 3 \mathrm{COOH} 3 \%$. Sampel selanjutnya dimasukkan ke dalam autoclave dan dipanaskan selama 3 jam. Sampel kemudian dikeluarkan dari autoclave dan didinginkan serta dinetralkan dengan $\mathrm{NaOH}$ 30\%. Setelah itu sampel dipisahkan, larutan dimasukkan ke dalam labu takar ukuran $250 \mathrm{ml}$ (larutan L1). Larutan kemudian dipipet sebanyak $10 \mathrm{ml}$ dan dimasukkan ke dalam erlenmeyer berukuran $250 \mathrm{ml}$ dan ditambahkan $25 \mathrm{ml}$ larutan Luff-Schoorl dengan pipet gondok dan $15 \mathrm{ml}$ aquades. Larutan kemudian dipanaskan selama 10 menit. Selanjutnya larutan didinginkan kembali dengan air mengalir dan ditambahkan $25 \mathrm{ml} \mathrm{H}_{2} \mathrm{SO}_{4} 25 \%$ dan larutan $\mathrm{KI} 20 \%$ perlahan lahan. Larutan dititrasi dengan $\mathrm{Na}_{2} \mathrm{~S}_{2} \mathrm{O}_{3} 0,1 \mathrm{~N}$ sampai warna kuning muda, ditambah indikator amilum $1 \%$ (terbentuk warna biru tua) dan dilanjutkan sampai warna biru tua hilang dan dicatat volume titrasi. Pengujian kadar glukosa hampir sama dengan pengujian kadar pati. Perbedaannya, mengganti $10 \mathrm{ml}$ larutan $\mathrm{L} 1$ dengan $10 \mathrm{ml}$ aquades dan dititrasi dengan $\mathrm{Na}_{2} \mathrm{~S}_{2} \mathrm{O}_{3}$.

\section{HASIL DAN PEMBAHASAN}

Konversi pati menjadi glukosa dipengaruhi oleh beberapa parameter diantaranya suhu, waktu, dan konsentrasi katalis. Pada penelitian ini, sampel yang digunakan adalah tepung biji durian dengan kandungan pati sebesar $36,4 \%$, dan asam asetat sebagai katalis. Konsentrasi asam asetat divariasikan berdasarkan asam asetat p.a, dan asam asetat (asam cuka) yang tersedia dipasaran. Ditinjau dari sifat fisik dan kimia, asam asetat adalah cairan tidak berwarna dengan bau tajam dan rasa asam, larut dalam air, karena polaritas ikatan yang tinggi, asam karboksilat $\mathrm{OH}$ membentuk ikatan hidrogen molekul yang lebih kuat dari pada alkohol yang menentukan kelarutan asam asetat yang tidak terbatas. Pengaruh ketiga parameter yang tersebut di atas, dapat dijelaskan sebagai berikut.

\section{Pengaruh Suhu Hidrolisis Terhadap Kadar Glukosa}

Gambar 1 menunjukkan bertambahnya suhu pada proses hidrolisis akan meningkatkan kadar glukosa. Kadar glukosa tertinggi diperoleh pada suhu $110{ }^{\circ} \mathrm{C}$ yaitu $0,634 \%$. Namun jika ditinjau kenaikan kadar glukosa per kenaikan suhu cukup besar juga. Ditinjau dari salah satu konsentrasi asam asetat (25\%), suhu yang berbeda $\left(70^{\circ} \mathrm{C}-90^{\circ} \mathrm{C}\right)$ dan waktu hidrolisis yang sama $(120$ menit), terjadi kenaikan perolehan glukosa sebesar $22.5 \%$, sedangkan pada suhu $90^{\circ} \mathrm{C}-110^{\circ} \mathrm{C}$, terjadi kenaikan perolehan glukosa sebesar $48,98 \%$. Hasil yang diperoleh pada penelitian ini sesuai dengan pernyataan (Anugrahini et al., 2013) semakin tinggi suhu hidrolisis, maka glukosa yang didapatkan juga semakin banyak.

Peningkatan suhu akan meningkatkan frekuensi tumbukan antar partikel reaktan sehingga mampu melewati energi penghalang akibatnya produk yang dihasilkan juga meningkat. Jika ditinjau dari hubungan suhu dan laju reaksi maka dapat dijelaskan, suhu berbanding lurus terhadap laju reaksi. Jika suhu dinaikkan maka laju reaksi akan berjalan semakin cepat sehingga energi kinetiknya lebih besar. Energi kinetik yang besar akan mempercepat terjadinya tumbukan (Mardina et al., 2014). 


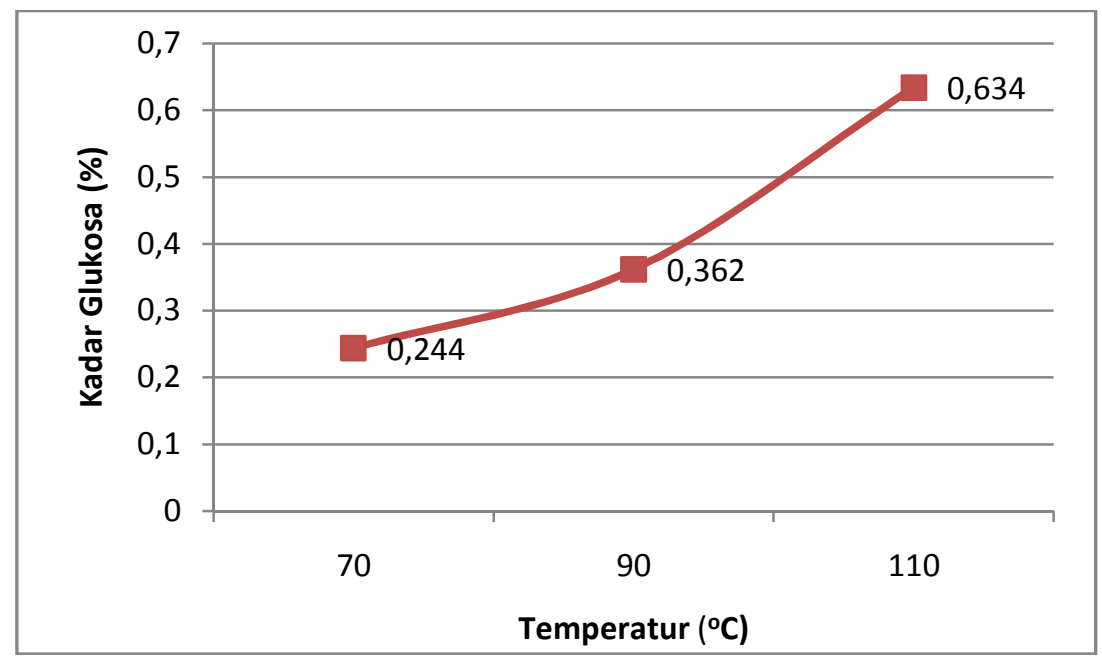

Gambar 1. Pengaruh suhu terhadap kadar glukosa

\section{Pengaruh Waktu Hidrolisis Terhadap Kadar Glukosa}

Waktu pengontakan adalah waktu yang dibutuhkan oleh reaktan untuk berubah menjadi produk dengan bantuan katalis. Gambar 2 memperlihatkan bahwa waktu hidrolisis berpengaruh terhadap kadar glukosa. Pada proses hidrolisis dalam penelitian ini, kadar glukosa tertinggi diperoleh pada waktu 240 menit. Jika ditinjau per waktu, kenaikan kadar glukosa cukup signifikan. Pada konsentrasi asam 25\% dan suhu $70^{\circ} \mathrm{C}$, kadar glukosa yang diperoleh dengan asam asetat p.a. pada waktu $120-180$ menit meningkat $12,5 \%$. Pada waktu 180-240 menit terjadi kenaikan kadar glukosa sebesar 13,33\%. Hal ini disebabkan karena semakin lama waktu hidrolisis, maka konversi pati menjadi glukosa akan semakin besar (Mastuti and Setyawardhani, 2010), gula polimer (pentosan) yang terurai akan semakin besar sehingga gula monomer yang dihasilkan semakin bertambah. Akan tetapi, pertambahan hasil tidak selamanya terjadi seiring bertambahnya waktu (Amborowati et al., 2016) karena suatu saat reaksi akan mencapai kesetimbangan.

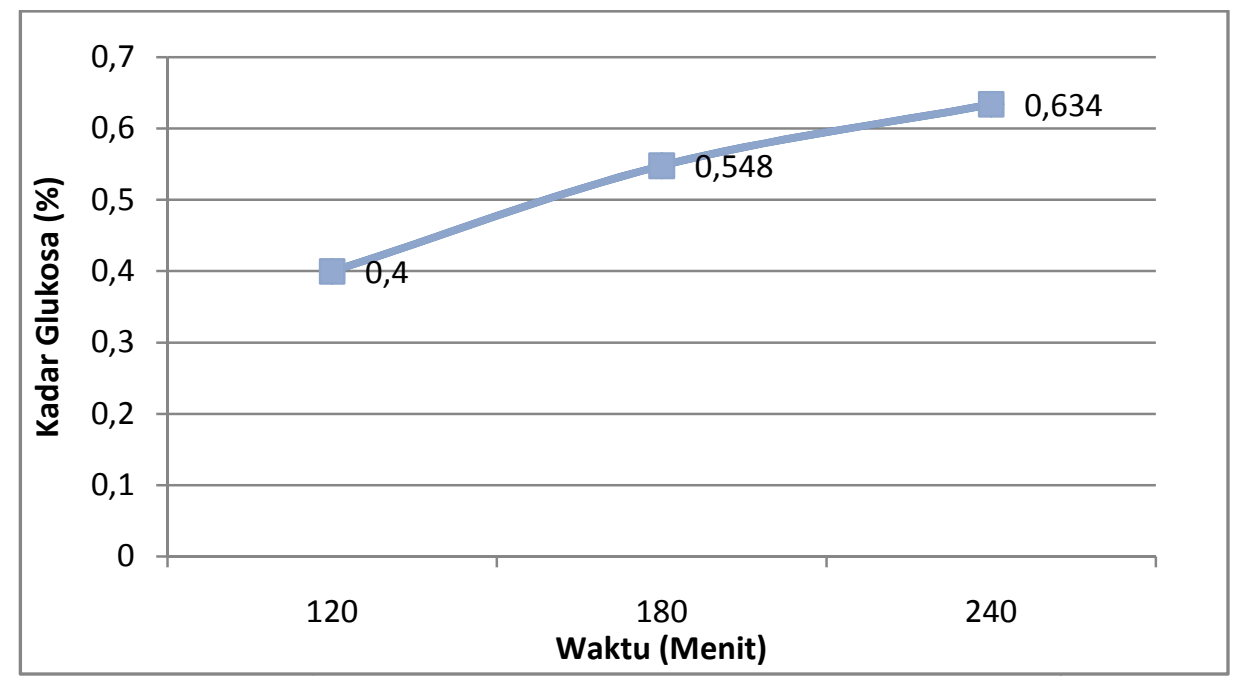

Gambar 2. Pengaruh waktu terhadap kadar glukosa

\section{Pengaruh Konsentrasi Katalis Terhadap Perolehan Glukosa}

Gambar 3 memperlihatkan kenaikan konsentrasi katalis menurunkan laju pembentukan glukosa. Kadar glukosa yang diperoleh pada konsentrasi asam asetat 2,5\%, suhu $110{ }^{\circ} \mathrm{C}$, dan waktu 240 menit, sebesar $158,5 \mathrm{mg} / \mathrm{dl}(0,634 \%)$. Jika ditinjau pada suhu dan waktu yang sama namun konsentrasi berbeda yaitu $10 \%$, kadar glukosa yang diperoleh menurun yaitu $65,5 \mathrm{mg} / \mathrm{dl}(0,262 \%)$. 
Fenomena ini sesuai hasil penelitian (Murniati et al., 2018) yang menyatakan, asam dengan konsentrasi terlalu tinggi akan menurunkan hasil hidrolisis karena glukosa akan sangat mudah terurai. Peneliti lainnya (Djaeni et al., 2012) menyatakan, penurunan kadar glukosa pada konsentrasi katalis yang lebih tinggi menyebabkan kadar air dalam katalis makin kecil sehingga kebutuhan $\mathrm{OH}\left(\right.$ dari ionisasi $\mathrm{H}_{2} \mathrm{O}$ ) untuk mengikat ion karbonium pada proses hidrolisis pati lebih sedikit dan glukosa yang dihasilkan lebih rendah.

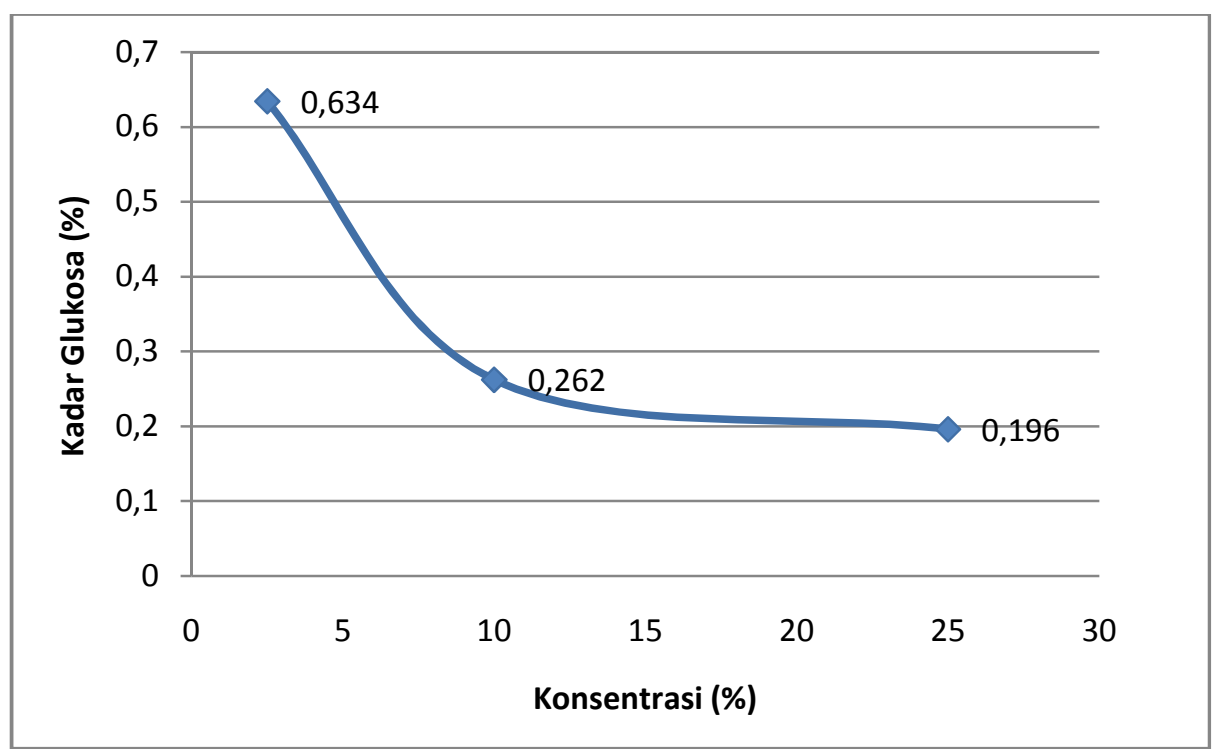

Gambar 3. Pengaruh konsentrasi asam terhadap kadar glukosa

Untuk perbandingan dicobakan juga hidrolisis menggunakan katalis asam asetat yang beredar di pasar tradisional. Pengujian hanya dilakukan untuk parameter suhu dan waktu hidrolisis sedangkan untuk konsentrasi katalis tidak diiujikan karena asam asetat yang di pasaran hanya mempunyai mempunyai 1 konsentrasi yaitu 15\%. Dari hasil penelitian menunjukkan asam cuka dapat digunakan sebagai katalis pada proses hidrolisis. Perbandingan kadar glukosa yang diperoleh dari asam asetat p.a dan asam cuka dapat dilihat pada Tabel 1.

Tabel 1.

Perbandingan penggunaan asam asetat p.a dan asam asetat yang dibeli di pasaran terhadap perolehan glukosa.

\begin{tabular}{|c|c|c|c|c|c|c|c|}
\hline $\begin{array}{l}\text { Asam } \\
\text { asetat } \\
\text { pasar } \\
(\%)\end{array}$ & $\begin{array}{l}\text { Suhu } \\
\text { hidrolisis } \\
\left({ }^{\circ} \mathrm{C}\right)\end{array}$ & $\begin{array}{l}\text { Waktu } \\
\text { Hidrolisis } \\
\text { (menit) }\end{array}$ & $\begin{array}{l}\text { Kadar glukosa } \\
\text { dengan asam } \\
\text { asetat p.a } \\
\text { (mg/dl) }\end{array}$ & $\begin{array}{l}\text { Glukosa } \\
(\%)\end{array}$ & $\begin{array}{l}\text { Kadar glukosa } \\
\text { dengan asam } \\
\text { asetat pasar } \\
\text { (mg/dl) }\end{array}$ & $\begin{array}{l}\text { Glukosa } \\
(\%)\end{array}$ & $\begin{array}{l}\text { Perbedaan } \\
\text { rata-rata } \\
\text { antara asam } \\
\text { asetat p.a dan } \\
\text { pasar } \\
(\%) \\
\end{array}$ \\
\hline \multirow{9}{*}{15} & \multirow{3}{*}{70} & 120 & 27 & 0,108 & 20,5 & 0,082 & \multirow{3}{*}{22} \\
\hline & & 180 & 31,5 & 0,126 & 23,5 & 0,094 & \\
\hline & & 240 & 33,833 & 0,135 & 27,5 & 0,11 & \\
\hline & \multirow{3}{*}{90} & 120 & 29,83 & 0,119 & 29 & 0,116 & \multirow{3}{*}{12,77} \\
\hline & & 180 & 36,167 & 0,145 & 30,5 & 0,122 & \\
\hline & & 240 & 40,5 & 0,162 & 33 & 0,132 & \\
\hline & \multirow{3}{*}{110} & 120 & 35,83 & 0,143 & 39,5 & 0,158 & \multirow{3}{*}{9} \\
\hline & & 180 & 49,833 & 0,199 & 41,5 & 0,166 & \\
\hline & & 240 & 60 & 0,240 & 60 & 0,24 & \\
\hline
\end{tabular}


Tabel 1 memperlihatkan bahwa Asam asetat di pasaran masih bisa digunakan sebagai katalis pada proses hidrolisis. Jika ditinjau dari suhu, peningkatan suhu juga meningkatkan perolehan kadar glukosa. Demikian juga dengan waktu hidrolisis, bertambahnya waktu hidrolisis akan meningkatkan kadar glukosa. Perbedaan rata-rata kadar glukosa yang diperoleh dengan katalis asam asetat p.a dan pasaran sebesar $14 \%$. Pada suhu $110^{\circ} \mathrm{C}$ dan waktu 240 menit, kadar glukosa yang diperoleh dengan katalis asam asetat p.a dan asam asetat pasaran sama yaitu $60 \mathrm{mg} / \mathrm{dl}(0,24 \%)$. Perbedaan ini disebabkan, konsentrasi asam asetat di pasaran yang tertera dilabel tidak sama dengan konsentrasi sebenarnya. Pada penelitian ini, kadar asam asetat pasaran tertera dilabel $25 \%$, namun sesudah distandarisasi ternyata hanya $15 \%$.

\section{SIMPULAN}

Biji durian mengandung pati sebesar 36,4\% dapat dijadikan bahan baku pembuatan glukosa. Meskipun asam asetat merupakan asam lemah, namun mampu menghasilkan glukosa sebesar $0,634 \%$ (158 mg/dl) pada konsentrasi $2,5 \%$, suhu $110{ }^{\circ} \mathrm{C}$, dan waktu 240 menit. Asam asetat yang dijual dipasar tradisional (asam cuka) juga dapat dijadikan katalis proses hidrolisis. Parameter lainnya seperti waktu dan suhu memberikan pengaruh yang signifikan. Kadar glukosa tertinggi pada penelitian diperoleh pada kondisi suhu $110^{\circ} \mathrm{C}$ dan 240 menit yaitu $0,634 \%$.

\section{UCAPAN TERIMA KASIH}

Terima kasih disampaikan kepada saudara Retno Hardillah dan Tri Sandi Ramadhan atas konstribusinya dalam melakukan penelitian ini.

\section{REFERENSI}

Amborowati, C., Andriani, U., Adytia, I. L., Feviasari, H., Hastin, T. K., and Adhiksana, A., 2016. Pengaruh waktu dan temperatur hidrolisis dalam proses sintesis furfural dari sekam padi dengan menggunakan metode hidrolisis dan dehidrasi. Journal of Research and Technology, 2(2), 72-77.

Anugrahini, S. F. A., Ismuyanto, B., and Indahyanti, E., 2013. Kinetika reaksi hidrolisis pati biji durian (Durio zibethinus Murr.) menjadi glukosa dengan variasi temperatur dan waktu. Kimia Student Journal, 2(1), 344-351.

Dewi, N. K. A., Hartiati, A., and Harsojuwono, B. A., 2018. Pengaruh suhu dan jenis asam pada hidrolisis pati ubi talas (Colocasia esculenta L. Schott) terhadap karakteristik glukosa. Jurnal Rekayasa Dan Manajemen Agroindustri, 6(4), 307. https://doi.org/10.24843/jrma.2018.v06.i04.p05

Djaeni, Anwar, M., Sofia, A., Afrisanti, L., and Wardani, D. H., 2012. Pemanfaatan tepung biji durian menjadi glukosa cair melalui proses hidrolisa dengan menggunakan enzim î-amilase. Jurnal Kovalen, 4(4), 35-47.

Hapsari, M. A. and Pramashinta, A., 2013. Pembuatan bioetanol dari singkong karet (Manihot glaziovii) untuk bahan bakar kompor rumah tangga sebagai upaya mempercepat konversi minyak tanah ke bahan bakar nabati.

Iryani, A. S., 2013. Proses Hidrolisis Pati Dalam Ubi Kayu. 8(April), 2-5.

Mardina, P., Prathama, H. A., and Hayati, D. M., 2014. Pengaruh waktu hidrolisis dan konsentrasi katalisator asam sulfat terhadap sintesis furfural dari jerami padi. Jurnal Konversi UNLAM, 3(2), 1-8.

Mastuti, E., and Setyawardhani, D. A., 2010. Pengaruh variasi temperatur dan konsentrasi katalis pada kinetika reaksi hidrolisis tepung kulit ketela pohon. Ekuilibrium, 9(1), 23-27.

Mei, N., Liu, B., Zheng, J., Lv, K., Tang, D., and Zhang, Z., 2015. A novel magnetic palladium catalyst for the mild aerobic oxidation of 5- hydroxymethylfurfural into 2,5-furandicarboxylic acid in water. Catalysis Science \& Technology, 3, 1-9. https://doi.org/10.1039/b000000x

Murniati, M., Handayani, S. S., and Risfianty, D. K., 2018. Bioetanol dari limbah biji durian (Durio zibethinus). Jurnal Pijar Mipa, 13(2), 155-160. https://doi.org/10.29303/jpm.v13i2.761

Neni, M., Ismuyanto, B., and Sutrisno, S., 2013. Pembuatan bioetanol dengan bantuan Saccharomyces cerevisiae dari glukosa hasil hidrolisis biji durian (Durio zibethinus). Kimia Student Journal, 1(1), 3642.

Nurjati, A. S., and Buchor, L., 2012. Pembuatan bioetanol hasil hidrolisa bonggol pisang dengan fermentasi menggunakan saccaromycess ce cereviceae. Jurnal Teknologi Kimia Dan Indutri, 1(1), 124-129.

Praputri, E., Sundari, E., Firdaus, F., Sofyan, S., 2018. Penggunaan katalis homogen dan heterogen pada proses hidrolisis pati umbi singkong karet menjadi glukosa. Jurnal Liibang Industri, 8, 105-110. 
Sistanto, S., Sulistyowati, E., Yuwana, Y., 2017. Pemanfaatan limbah biji durian (Durio zibethinus Murr) sebagai bahan penstabil es krim susu sapi perah. Jurnal Sain Peternakan Indonesia, 12(1), 9-23. https://doi.org/10.31186/jspi.id.12.1.9-23

Uppal, S. K., and Kaur, R., 2011. Hemicellulosic furfural production from sugarcane bagasse using different acids. Sugar Tech, 13, 166-169. https://doi.org/https://doi.org/10.1007/s12355-011-0081-5/. 